\title{
Shiite Geopolitics Contemporary Shiite Geopolitical Theories and Terms
}

\author{
Bayan Al Safi \\ PhD student/ Department of Political Science, Sociology and Cultural Studies/ H.S. Skovoroda Kharkiv \\ National Pedagogical University/
}

\begin{abstract}
Ideological doctrinal theories were developed specifically for Shiite geopolitics as the basis for the implementation of the Iranian expansionist strategy and attempts to make the Iranian sectarian project successful by controlling the countries located in its vital area. In the first decade of the Islamic revolution, Shiite geopolitical theories were based on Iran's outing its geographical borders and turning it into the axis of the Islamic world. Thus, Tehran took a liberty of reaching out to social, cultural and sectarian components in other countries with the aim of building Muslim Shiite regimes under the leadership of Iran.

The paper examines the manifestation of the return of geopolitics in the 21st century, in particular, the Iranian Shiite geopolitics and the expansion of Shiite political Islam, especially after the Iranian role demonstrated the armed aspect of sectarianism.
\end{abstract}

Keywords: Middle East, Velayat-e Faqih, Umm al-Qura states, Mahdi global state, Messianism, Iranian strategy, soft Shiism, hard Shiism, Shiite politicization.

The relevance of the research topic is due to the severity of the problems associated with Shia Islam. Shiite doctrine has become an independent representative in Iran's international relations and has acquired a highly influential official character in public awareness, political processes and expansionist ambitions. Accordingly, the term "Shiite geopolitics" appeared in international political studies, consequently followed by other derivative terms such as "soft Shiism", "smart Shiism", "hard Shiism" and "Shiite politicization". Shiite geopolitics relied on several theories that emerged in the late twentieth century and expanded their applications in the early twenty-first century.

Purpose of work: We can formulate the purpose of this study as identifying theories and terms achieved by Iranian strategic thought in the late 20th and early 21 st centuries, in the process of shaping Islamic politics and attempts to dominate on a global scale. Measuring the religious and political influence of Iran by studying Shiite geopolitical theories and their implications for regional events in the Middle East, given that, the basis of these theories, regardless of their differences coincide with the goal and requires considering regional states as able to influence possible scenarios and bearing their consequences.

Methodology: The study used a historical approach to investigate the role played by Shiite culture within the grassroots and religious political leaderships in the development of Shiite geopolitics. The descriptive analytical approach by gathering information about the Shiite ideology and the phenomenon of the Shiite geopolitics and its terminology, analyzing it and predicting its possible outcomes.The systemic approach by examining the theoretical and intellectual contexts. The research depends primarily on references in the Arabic language.

\section{Shiite Geopolitics}

\section{Contemporary Shiite geopolitical theories and terms}

Swedish scientist and politician Rudolf Kjeilen (June 13, 1864 - November 14, 1922) came up with the term "geopolitics" and used it to justify and facilitate aggressive expansion in Europe. Despite this sad legacy, 
geopolitical events have served to build peaceful relations between countries and achieve prosperity ${ }^{1}$. Rudolf Kjeilen who was the first to use the term geopolitics in 1905, defined it in his book "The State as a LifeForm" as "the study of the natural environment of the state". The most important aspect of the state is power, since the life of states depends on education, culture, economy and government". Kjeilen tries to emphasize that the ultimate goal is harness geography for the state, in other words, the decision maker can make the geographic location a source of strength for the state in expressing its political positions. ${ }^{2}$

Global geopolitics varied in intensity and may have receded in the twentieth century, but in practice it returned in the early twenty-first century. The American magazine Foreign Affairs published an article "The Return of Geopolitics" on April 17, 2014, in which it is confirmed that the return of geopolitics was evident in the politics of the 21 st century, "geopolitical rivalries have stormed back to center stage. Whether it is Russian forces seizing Crimea, China making aggressive claims in its coastal waters, Japan responding with an increasingly assertive strategy of its own, or Iran trying to use its alliances with Syria and Hezbollah to dominate the Middle East, old-fashioned power plays are back in international relations"3.

Dr. Khalil Hussein, focused on the core issues of geopolitics, namely transparent borders, geographic barriers, the living environment and external expansion, to describe Iran's strategies and Shiite geopolitics in his book Geopolitics. "Shiite geopolitics has focused on the entire Iranian politics within the living environment of the Iranian state through the Iranian doctrinal, historical and pragmatic strategy prepared by informed decision-makers. This strategy defines the living environment of the Iranian state and raises the principle of transparent borders for geographic expansion consistent with Iran's interests, while giving priority to target countries to form the Shiite axis and Iran's geographic barriers". Shiite geopolitics has entered the forefront of the regional and international political scene with the aim of forming a cross-border Shiite movement led by Iran. Shiite geopolitics aims to go beyond the Iranian borders, where Iranian interests are in line with its living environment with the aim of controlling land or territory suitable for an Iranian state. The goal is to form geographic barriers beyond the borders of the state and gradually link with the Iranian state to achieve the ultimate goal of expansion in accordance with the strategies of Iranian decision-makers as leaders of the Shiite geopolitical project since $1979 .^{5}$

Iran's strategy is aimed at achieving global power by creating ubiquitous and multidirectional centers of executive power, of both ideological and pragmatic character, based on real details, and using them to draw up plans for the nearest future without specific constants, to find ways to challenge Western strategies. As a result of extensive political research on Iran and its strategy, Shia political terms have emerged, based mainly on the political science terminology of power, such as "soft Shiism", "hard Shiism", "Shiite politicization" and "Shiite fusion". The term "soft Shiism" refers to the strengthening of the motivational process, influences the way of thinking in the society as a standard of culture, included in the educational and cultural system of Shiite society. The term "soft Shiism" appeared in research and political articles on the study of the Islamic revolution and its geopolitical ambitions. The nature of the theocratic regime and the polarization of Shiite societies in the Islamic world through Khomeini's religious and political discourse and political slogans, in other words, informational and psychological impact, aimed at forming ideological attitudes among the masses and have an effective impact. "Soft Shiism" employs the methods of the Leftists, who managed to conquer Europe and America and spread their ideas in them, which was reflected in the growth of the percentage of voters for the leftist parties in Europe. ${ }^{6}$ The Italian Marxist A. Gramsci in his concept of cultural hegemony attaches great importance to civil society. According to his theory, this institution is a full-fledged actor within the state and is able to independently resist external challenges. ${ }^{7}$

\footnotetext{
${ }^{1}$ New World Encyclopedia / https://www.newworldencyclopedia.org/entry/Rudolf_Kjell

${ }^{2}$ Geopolitics / https://political-encyclopedia.org/dictionary

3 James Clarke Chace(Walter Russell Mead)/ The Return of Geopolitics/ May/June 2014/

https://www.foreignaffairs.com/articles/china/2014-04-17/return-geopolitics

${ }^{4}$ Dr. Khalil Hussein/ Geopolitics / Publisher Dar Al-Manhal Albnani/ First Edition 2009 / p. 1252009

${ }^{5}$ Dr. Hamdi Obaid / Read on the strategy of spreading Shiism and the role of Iran in the American strategy// 6/11/2015 / /

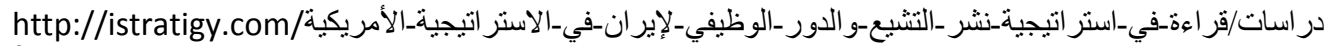

${ }^{6}$ Soft Shiism/ http://alrased.net/main/articles.aspx?selected article no=4866

${ }^{7}$ Shevchenko, M.A., Kunshikov S.V., / A. GRAMSHI'S CONCEPT OF CULTURAL HEGEMONY AS
} 
Gramsci associated the concept of "ideology" and its power with a decrease in the level of contradictions in the public discussions and with the achievement of harmony in society. Shiite leaders have used this theory to mobilize Shia civil society into a unified ideology through soft Shiism. Globalization and the Internet are a means of supporting soft Shi'ism, according to the statement of the Supreme Leader of Iranian states Ayatollah Ali Khamenei: "The media in this era has a destructive potential equivalent to an atomic bomb." 8 Media can be used to control public opinion, diminish the importance of opponents and refute competing ideologies. Dozens of satellite channels and various websites have been created, whose target audience is minds of different segments of Islamic societies in different languages. Researcher Dr. Hamdi Obeid's works, published on the Istratigy website, highlight the most important soft actions that help spread Shi'ism and achieve goals of Shiite geopolitics, including drawing supporters of Shia Islam among lawyers and judges, creating charitable, cultural or medical organizations, an intense presence in media, the use of arts and a growing exaggeration and repetition to conquer minds in a psychological, instigative and political way, by granting scholarship and promoting religious tourism. ${ }^{9}$

Religious and political ties began to influence the entire public thought, which led to the emergence of the term "politicization of Shiites." The term has been used in multiple political studies of the causes and consequences of changes in the structure of Shiite sects and their direction in the arena of guerrilla and fractional auctions and political trade under the pretext of their support, representation of their interests and protection of their rights. The term "politicization of Shiites" appeared in an article by Iraqi scholar Khaled Al-Ardawi, published on September 22, 2013 on the Middle East Online website, entitled "Politicization of Shiites, negative impact on national security." ${ }^{10}$ One of the most extensive studies where the term is used is The Encyclopedia of Iran and the Politicization of Shiites, published by the Al Mazma Research Center in Dubai in 2018. ${ }^{11}$

\section{Shiite geopolitical theories}

Iran is a central contact for Shiite societies around the world and the center of Shia Islam. Numerous Iranian geostrategic theories are expansionary, going beyond the geographic reach of Iran to support regional and international doctrinal influence, making them competent to exercise control over Shiite societies living within a Shia geopolitical framework. The high political Shiism has moved from intrastate to interstate level and is striving for globalization.

\section{Theory of the global Mahdi state}

Messianism is the mental base of Shiite geopolitics and one of the crucial elements of Iranian national identity. The doctrine of the expectation of the Mahdi or the messianic expectation of the emergence of the Mahdi in Shiite doctrine is not an exclusive feature of the Islamic monotheistic religion, but is also contained in other monotheistic religions under the term "savior" or "savior of human positivist thought." 12 Expectation of the Mahdi is a state of preparation and self-preparation contributing to becoming an ideal person, which leads the world to prosperity, justice and tranquility, high spiritual development and sincerity, subject to observance of Sharia law and dedication to the application of its provisions in all their aspects. ${ }^{13}$ There is a general belief, which is the reason of a moral agreement between Christian and Shia thought, that the expected Mahdi is Jesus Christ himself. ${ }^{14}$

METHODOLOGICAL BASIS OF INFORMATION PSYCHOLOGICAL WAR

\footnotetext{
${ }^{8}$ Imam Khamenei's vision of soft war/ http://alwelayah.net/?cat=20

${ }^{9}$ Dr. Hamdi Obaid / Read on the strategy of spreading Shiism and the role of Iran in the American strategy / http://istratigy.com http://istratigy.com/

${ }^{10}$ Khaled Al-Ardawi/ Politicizing the Shiites ... The negative impact on national security / 29/09/2013 / https://middle-eastonline.com/

${ }^{11}$ Ibrahim al-Miqdadi / Encyclopedia of Iran and Political Shi'ism / Dubai / Al-Mazama Center for Studies and Research 2018/ https://books.google.com.ua/books?id=B1aEDwAAQBAJ\&printsec=frontcover\&hl /

12/ Nahida Muhammad Ziol /The doctrine of waiting for the Mahdi in contemporary Islamic political thought/ Council of the College of Political Sciences / University of Baghdad Political Science

${ }^{13} \mathrm{Al}$ Rasd Al Akaadi Center/ The doctrine of waiting is not a dysfunctional doctrine of the people /https://www.alrasd.net/arabic/questions/880

${ }^{14}$ Mohammed Mohammed Kazlak/The ten destructive signs of religious heritage/ 2018, 196 pages. pp 38
} 
The influence of the theory of expectation of the Mahdi on Iranian leadership dates back to 1891. The highest religious authority, Mohammad Hasan al-Shirazi, wrote a letter to Shah Nasser al-Din, in which the government was pledged to cancel the tobacco trade agreement signed with the British company, on the grounds that tobacco consuming was contrary to the expectations of the Imam Mahdi. ${ }^{15}$ Support for the Mahdi expectation theory continued during the ruling of Shah Muzaffar al-Din in 1905, which resulted establishing in the Iranian constitution of 1906 the doctrine of the twelfth "hidden Imam" as the official doctrine. Article 2 of the constitution states that the Shura Council has no right to issue laws, that contradict the norms of Islam and the Mahdi doctrine. ${ }^{16}$ In the course of the struggle for the implementation of the development models of the Mahdi Expectations doctrine, the idea of Velayat-e Faqih appeared. Iran's political system differs from other global political systems with a unique constitutional advantage, which is the existence of an institution called "Velayat-e Faqih" or "the Governance of the Jurist", located at the top of the pyramid of power, and according to the Iranian constitution, al-Fakih has broad powers. The Velayate Faqih theory originated in the early nineteenth century in the work of Sheikh Ahmed al-Naraki, author of The Return of the Days, who died in $1829 .{ }^{17}$ The idea of Velayat-e Faqih is analyzed as a clever bypass of the Mahdi expectation doctrine. Al-Faqih is considered the deputy of the expected Mahdi, he has most of his powers, but not all, for example, he has no right to declare jihad, which only Mahdi is eligible for. This logic was adopted and realized as a result of the Iranian revolution of 1979, Iran is now the state of Velayat-e Faqih, which paves the way for the emergence of the Mahdi. ${ }^{18}$ The absolute guardianship of Velayat-e Faqih and its frame of reference in accordance with Imam Khomeini was included in the Iranian constitution at the fifth session of the Shura Council, in the context of emphasizing loyalty to Imam Khomeini and the embodiment of the state in accordance with the ideas of the leader of the revolution. ${ }^{19}$

Historically, Velayat-e Faqih has been a reasonable and appropriate solution to the dilemma of the prospect of the expected Mahdi. However, from a fundamentalist point of view, the doctrinal requirements for the principles of this doctrine and its general paradigm "Jurisprudence" are simply an innovation that helps create a new type of absolute domination, not only over Iran. The practice of Shia imams is in compliance with the target direction of Iran's strategy, is linked to the main priorities and regulates most of the political, cultural, religious and social issues. Former Iranian President Mahmoud Ahmadinejad turned the Mahdi doctrine into a political theory, believing that his government is an interim government that paves the way for the creation of a global Mahdi government. In his speech before the participants of the Mahdism Conference in Tehran in 2005, he stated: "The Islamic Republic and the Velayat-e Faqih regime have no other intention than to prepare for the establishment of a global government, since the Imam al-Mahdi will rule the universe through this government. ${ }^{20}$ The vision of the theory is based on the idea of creating a global Mahdi state, which should provide all the elements of power for its rise and success, the failure to achieve these goals means the remaining major obstacles to the creation of a global Mahdi government.

To satisfy Iran's ambitions, it was necessary to look for alternative theories. The global Mahdi state theory ran into numerous obstacles due to the lack of agreement between Iranian politicians and Shiite scholars regarding the absolute powers of Velayat-e Faqih. It is difficult for the Shiite community to accept a person or group of people as representatives of the Mahdi, due to his attributes of infallibility and justice, which are exclusively Divine.

\section{Revolution export theory}

Exporting revolution is considered one of the most important functions of the Islamic state of Iran. The goal of exporting the revolution, according to the vision of Iranian politics, is to support the oppressed and Muslims around the world. Hence, their support is a duty. The export of revolution is one of the most

\footnotetext{
15/ Talal Al-Majzoub, "Iran from the Constitutional Revolution to the Revolution," p. 108 /Ibn Rushd Press

${ }^{16}$ Mohsen Kadyor, theories of governance in Shiite jurisprudence /Beirut, Dar Al-Jadeed, 2000 AD, 206 pages. P / 126 /

${ }^{17}$ Shafiq Shqeir /The theory of wilayat al-faqih and its implications in contemporary Iranian political thought

https://www.aljazeera.net/specialfiles/pages/b89d2831-2b46-462f-9b5c-776d1b0edd80

18/ Dr. Elias Belka/ Mahdi is a dangerous future doctrine / Studies / الدر اسات https://www.alrashad/ .org/ .html الدار اسات/المهدوية_عقبدة_مستقبلية_خطرة. html

${ }^{19}$ Mohsen Kadyor, Theories of governance in Shi'a Jurisprudence, pp. 33-34
}

${ }^{20}$ каsra Naji, Ahmadinejad: The Secret History of Iran's Radical Leader (Berkeley: University of California Press, 2008$), 106$. 
important initial foundations of the Iranian Principle, where there should be no restrictions in achieving this goal, the ultimate goal being to create a just global government.

Two years after the success of the Islamic Revolution, the Iranian government newsletter Shahid announced on April 7, 1981 a global roadmap of Iran led by Velayat-e Faqih. The Perspective Map requires the annexation of the entire world to Iran, beginning from the overthrow of Iraq as the gateway to the liberation of the Arab world from the Persian Gulf to the Atlantic Ocean, right up to uniting the entire Islamic world from Morocco to Indonesia. "We want the revolution to be everywhere and to be exported"22. According to Khomeini, the legitimacy of the Iranian revolution is presented in the logic of open borders, since it does not recognize any borders and geographic boundaries, is based on the principle of unity of all Muslims, who amount for at least a billion people, in other words, entering the international arena as an ideological outpost of the Muslim world.

The theory and principle of the export of the Iranian revolution highlighted the internal contradictions between Muslims and gave rise to Sunni and Shiite terrorist organizations. Countries with Sunni regimes viewed the export theory as the return of geopolitical wars, the absorption of their countries through the spread of sectarianism. This aggravated internal Islamic controversies and led to devastating wars, the first of which was the Iraqi-Iranian war in 1980, followed by proxy wars in Syria and Yemen.

The mass demonstrations taking place today in Iraq and Lebanon express a new type of Shiite agreement against the revolution export theory, and is considered one of the most important signs of its decline. The "agreement" between the protests in the two countries is mainly due to the influence of Iran. Both countries face the same issues regarding the Iranian project to undermine the concept of a civil state and its institutions and create a different type of state. ${ }^{23}$

\section{Theory of the State of Umm Al-Qura}

The Heartland theory, formulated by British scientist Halford John Mackinder in 1904, was presented in his article "The geographical pivot of history". ${ }^{24}$ In Heartland theory, the scope of geopolitical analysis covered the entire world. The theory states that the world has a heart and the one who rules it commands the whole world. The country that rules the heart of the world will be a superpower and will be protected. This country has sufficient security, which allows it to use extensively its resources and capabilities to become developed in all areas and turn into a major economic power, as well as create an excellent military force. According to Halford John McKander, "command over the World-Island will not be achieved without command over the heart of this world." According to this theory, political history is a continuous struggle for control of the world between continental and naval forces, and if land forces manage to control the world, they will defeat the naval powers.

The Heartland theory has proven attractive due to advances in geopolitical thought. The foundations of this theory were used to form the theory of the State of Umm Al-Qura. This theory was developed and formulated by the Iranian politician Mohammad Javad Ardashir Larijani.

Umm Al-Qura is a doctrinal theory based on a purely Shiite vision that is used to define the relationship between the Islamic Republic of Iran and the Arab world in particular, as well as the Islamic world in general, provided that Iran is the political and doctrinal center of the Islamic world, as this center is under the guardianship and leadership of Muslims around the world. Larijani formulated his theory, which provides for the religious and legal aspects of Shiite doctrine, making it a theory focused on Iran and its external behavior in the surrounding Islamic world, based on the fact that the countries of the Arab world are considered as provinces that do not agree with the fact that Shiite jurists, "keepers of Islam," live in Tehran. The aim of the theory is to make the Islamic Republic of Iran a central Shiite empire that would extend across Islamic countries using the spread of thought through intimidation and coercion, money and weapons.

\footnotetext{
${ }^{21}$ Magazine (Shahid). Tehran issue (April 7, 1981 ). ملة شهيد

22 13-Khomeini 9/26/1983

${ }^{23}$ Tony Poulis/ Beirut Greetings to Baghdad ... Uprising in the face of Iran's arms / / 20 October 2019/

${ }^{24}$ Charles Kruszewski, "The Pivot of History", Foreign Affairs, April 1954
} 
The Shiite centralization in the Islamic world regards Iran as the State of Umm Al-Qura ${ }^{25}$ with the political system Velayat-e Faqih.

The Iraqi politician Firas Elias in his essay "Shiite Geopolitics and the Geostrategic Imagination of Iran: Spheres of Influence," published in the fourth issue of the Labab Al-Jazirah Research Center magazine ${ }^{26}$, considers the problematic issue of the formation of Shia geopolitics is necessary for Iran's strategy.

\section{Conclusion}

The Islamic Republic of Iran was based on the ideology of Shiite thought and relies on peculiar methods that provide for the factors of domination and spread of influence in the doctrinal strategy, as well as the implementation of the concept of national security, supported from the outside, and the use of Shiite culture by creating well-designed geopolitical theories which it tries to involve to unite non-Iranian regions using demographics and doctrinal ideas. The expected collapse of Shiite geopolitics and its theories is evidenced by increased protests from the most powerful allies of this ideology, as well as through political setbacks in Iraq, Lebanon, Syria and Yemen.

\section{About the author}

Bayan Al Safi

PhD student/ Department of Political Science, Sociology and Cultural Studies/

H.S. Skovoroda Kharkiv National Pedagogical University/

The supervisor: Bezruk Oleksandr Oleksandrovych, PhD, Associate Professor in H.S. Skovoroda Kharkiv National Pedagogical University.

E-mail: bayanalsafi@gmail.com /

Mobile: +380636992650

https://orcid.org/0000-0001-9440

\section{References}

[1.] Al Rasd Al Akaadi Center/ The doctrine of waiting is not a dysfunctional doctrine of the people

[2.] Charles Kruszewski, "The Pivot of History", Foreign Affairs, April 1954

[3.] Dr. Elias Belka/ Mahdi is a dangerous future doctrine / Studies / https: //www.alrashad/ .org / studies / Mahdia-doctrine-futuristic dangerous. Html

[4.] Dr. Hamdi Obaid / Read on the strategy of spreading Shiism and the role of Iran in the American strategy / http://istratigy.com

[5.] Dr. Khalil Hussein/ Geopolitics / Publisher Dar Al-Manhal Albnani/ First Edition 2009 / p. 125

[6.] Geopolitics / https://political-encyclopedia.org/dictionary

[7.] Ibrahim al-Miqdadi / Encyclopedia of Iran and Political Shi'ism / Dubai / Al-Mazama Center for Studies and Research 2018/ https://books.google.com.ua/books?id=B1aEDwAAQBAJ\&printsec=frontcover\&hl=ru\&source=g bs_ge_summary_r\&cad=0\#v=onepage\&q\&f=false

[8.] Imam Khamenei's vision of soft war: http://alwelayah.net/?cat=20

[9.] James Clarke Chace(Walter Russell Mead)/ The Return of Geopolitics/ May/June 2014/ https://www.foreignaffairs.com/articles/china/2014-04-17/return-geopolitics

[10.] Khaled Al-Ardawi/ Politicizing the Shiites ... The negative impact on national security / 29/09/2013 / https://middle-east-online.com/

[11.] Firas Elias / Shiite geopolitics and Iranian geostrategic imagination: areas of influence and building influence/ 05/12/2019 https://studies.aljazeera.net/ar/reports/2019/12/191205103235122.html

[12.] Khomeini 9/26/1983

[13.] Kasra Naji, Ahmadinejad: The Secret History of Iran's Radical Leader (Berkeley: University of

\footnotetext{
${ }^{25}$ Nabil Ali Al-Atoom / "Iran and the Promised Shiite Empire" pp. 146-152 / Chapter Three/ Al-Asr Center for Strategic and Future Studies 2013

26/ Firas Elias / Shiite geopolitics and Iranian geostrategic imagination: areas of influence and building influence/ 05/12/2019 https://studies.aljazeera.net/ar/reports/2019/12/191205103235122.html
} 
California Press, 2008), 106.

[14.] Magazine (The Martyr). Tehran issue (April 7, 1981)

[15.] Mohammed Mohammed Kazlak/The ten destructive signs of religious heritage/ 2018, 196 pages. pp 83

[16.] Mohsen Kadyor, Theories of governance in Shi'a Jurisprudence, pp. 33-34

[17.] Mohsen Kadyor, theories of governance in Shiite jurisprudence /Beirut, Dar Al-Jadeed, 2000 AD, 206 pages. $\mathrm{P} / 126$

[18.] Nabil Ali Al-Atoom / "Iran and the Promised Shiite Empire" pp. 146-152 / Chapter Three/ Al-Asr Center for Strategic and Future Studies 2013

[19.] Nahida Muhammad Ziol /The doctrine of waiting for the Mahdi in contemporary Islamic political thought/ Council of the College of Political Sciences / University of Baghdad Political Science /

[20.] New World Encyclopedia / https://www.newworldencyclopedia.org/entry/Rudolf_Kjell.

[21.] Shafiq Shqeir /The theory of wilayat al-faqih and its implications in contemporary Iranian political thought https://www.aljazeera.net/specialfiles/pages/b89d2831-2b46-462f-9b5c-776d1b0edd80

[22.] Shevchenko, M.A., Kunshikov S.V., / A. GRAMSHI'S CONCEPT OF CULTURAL HEGEMONY AS METHODOLOGICAL BASIS OF INFORMATION PSYCHOLOGICAL WAR.

[23.] Soft Shiism/ 1rased.net/main/articles.aspx?selected_article_no=4866

[24.] Talal Al-Majzoub, "Iran from the Constitutional Revolution to the Revolution," p. 108 /Ibn Rushd Press.

[25.] Tony Poulis/ Beirut Greetings to Baghdad ... Uprising in the face of Iran's arms / / 20 October 2019.

Note: Research papers depend primarily on references in Arabic, translated by the author Bayan Al Safi. 